\title{
The beidellite clays from the Bełchatów lignite deposit as a raw material for constructing waterproofing barriers
}

\section{Introduction}

In the last 25 years of the 20th century the issues of the natural environmental became one of the most important civilizational challenges. Their tackling is particularly serious as the sources of the problem are much diversified. Let us consider the negative impacts of landfills, accumulating both industrial and communal waste. The nature of the materials disposed of decides on whether such sites become sources polluting underground and surface waters, soils and even the air. In addition, most of the landfills are specific chemical reactors, in which various chemical, geochemical, physical and mechanical processes of different rates and intensities take place. They lead to the formation of many compounds and substances, some of which can be released to a closer or more distant neighborhood. Not all are neutral, part of them may even be toxic, for instance those containing heavy metals hazardous to biological life. The spreading of such transformation products may be substantial, due mainly to the migration of effluents (Brański 1994).

The contamination of soils, surface waters and groundwaters around landfills depends on many factors. The most important are two groups: first, the type of accumulated waste and the contamination load they represent, and second, the nature of the grounds or rocks

* Professor, The Mineral and Energy Economy Research Institute of the Polish Academy of Sciences, Krakow, Poland; e-mail: trataj@agh.edu.pl

** Ph.D. Eng., AGH University of Science and Technology, Krakow, Poland; e-mail: hycnar@geol.agh.edu.pl

*** Ph.D. Eng., AGH University of Science and Technology, Krakow, Poland; e-mail: pbozecki@agh.edu.pl 
underlying the landfill, particularly their filtration, sorption and sealing properties. Natural impermeable geological barriers are represented by clay rocks forming the substrate of the landfill: they can effectively minimize negative impacts of the contaminants on the soil-water system. The criteria referring, among others, to locating the landfill types are contained in the Regulation of the Minister of the Environment (Journal of Laws No. 71, item 549). In turn, Instruction No. 337 of the Institute of Building Techniques (Wysokiński ed. 2007) presents the geological-engineering parameters that should be met by clay grounds making the substrate of landfills to secure the soil-water environment from the migration of contaminants.

Many years of research and practical experience indicate that the function of the natural, impervious layers can be fulfilled by waterproofing barriers constructed of clay rocks possessing the required parameters. The latter are inherited results of mineral and chemical compositions as well as physico-chemical and physico-mechanical properties of such rocks.

\section{Applicability criteria of clay raw materials to constructing waterproofing barriers}

Constructing waterproofing barriers within, under and around landfills was a new trend in the use of clay rocks. Therefore, the criteria controlling this engineering segment had to be defined and legally regulated. The basic document was issued as the Regulation of the Minister of the Environment of March 242003 on the requirements referring to the localization, construction, exploitation, maintenance and reclamation of landfills of various types in accordance with the Polish legislation (Journal of Laws 2003, No. 61, item 549), which up to now has had a number of amendments. Other proposals, summarizing research on the application of clay rocks to constructing sealing barriers, were published in Poland by branch institutes (Aprobata techniczna... 2002; Wysokiński ed. 2007).

In an evaluation of the required properties of clay rocks, the first of these instructions (Aprobata techniczna... 2002) takes the results of mineralogical and chemical analyses and geological-engineering tests into consideration, establishing the following parameters:

- grain size distribution, chemical composition and mineral composition,

- plasticity index,

- ion exchange capacity and the sequence of cation adsorption.

These parameters are the basis of distinguishing four respective classes of clay rocks: the best, good, moderate and unsuitable.

The other instruction (Wysokiński ed. 2007) specifies a wider list of parameters to be established in evaluating the applicability of clay rocks for waterproofing purposes. The list contains: grain size distribution and the contents of clay, sand and gravel fractions; plasticity index; liquid limit; linear shrinkage; contents of organic matter and $\mathrm{Ca}$ carbonates, compression strength; and deformation strength. The applicability of clay rocks to constructing mineral waterproofing barriers is determined as a numerical value from the range of $0-100$, 
resulting from a degree of fulfilling the criteria mentioned above. The rock can fall into one of three classes:

- very suitable (above 80 ),

- suitable (40 to 80 ),

- unsuitable without a special treatment (below 40).

Poland is a country rich in clay rocks, which are highly differentiated considering their age (Paleozoic-Cenozoic), genesis and diagenetic alterations. For these reasons, they have a diversified mineral and chemical composition, structural and textural development and physico-chemical and mechanical properties.

Research on the applicability of domestic clay rocks to environmental protection technologies have been carried out since the 1990s and show than the best are the loose, distinctly fine-grained rocks, containing minerals of the smectite group as dominant components. The characteristics of their varieties that can be used in constructing waterproofing barriers were prepared by Ratajczak and Stachura (2004) and Ratajczak et al. (2015), following the directions contained in „Aprobata techniczna...” (2002). Simultaneously, further investigations were continued with the aim of extending the list of clay rocks suitable due to introducing modifications of their mineral-chemical composition and physico-chemical properties. A growing market demand for the clay rocks that can be used in environmental protection technologies has resulted in extending research to the clay rocks that are mineral raw materials associated with a major commodity mines, particularly to those occurring in the overburden of lignite deposits.

\section{Beidellite clays of Belchatów and their technological potential}

The Tertiary lignite formation of the Bełchatów region contains four lithological complexes: clay-sand, clay-coal, coal and sub-coal ones (Fig. 1, Czarnecki et al. 1992). Beidellite clays represent the prevalent type of sediments in the clay-sand complex, where they form two varieties: beidellite and kaolinite-beidellite (Wyrwicki 1993). These clay rocks occur in two exploitation parts of the Bełchatów lignite open pit, i.e., in the Bełchatów and Szczerców exploitation fields. They are developed as several horizons with the thickness from single meters to several tens of meters, while in the zones of the deposit marginal faults they are even up to $40-50 \mathrm{~m}$ thick. Several established possibilities of utilizing these clay rocks were the basis to recognize them as the associated rock types of the Bełchatów deposit (Jończyk and Skórzak 2001). In the 1990s they were used for producing ceramic tiles by the ceramic plants in Opoczno. Other attempts to find their use included foundry and drilling purposes, and other types of ceramic production: light-weight aggregates (keramsite, aluminoporite) and common building materials (Ratajczak et al. 2005, 2007). The beidellite clays were mined in the Bełchatów field in the years 1989-2007, when approximately 1 million $\mathrm{Mg}$ were extracted and utilized. In turn, the beidellite clays of the Szczerców field have been selectively exploited and stored as anthropogenic deposits since 2010. Up to now their 




Fig. 1. Lithostratigraphic division of the lignite-bearing Tertiary in the Bełchatów deposit according to after Czarnecki et al. 1992

dashed line: erosional discontinuity

Fig. 1. Podział litostratygraficzny trzeciorzędu węglonośnego w złożu Bełchatów według Czarnecki i in. 1992 linia przerywana: powierzchnia nieciągłości erozyjnej

anthropogenic accumulations have reached approximately 35,000 $\mathrm{Mg}$ and represent a resource that can be utilized in the future.

The mineral composition of the clay rocks of Bełchatów, which have beidellite as the major mineral, gave rise to initiate the investigations on their adsorption properties (see for instance Ratajczak et al. 1992). The results were encouraging enough to recognize them as mineral adsorbents. They are capable absorbing heavy metals from water solutions, among others $\mathrm{Cr}$ cations (Bajda and Ratajczak 2005) and also $\mathrm{Co}, \mathrm{Cu}, \mathrm{Ni}, \mathrm{Pb}$ and $\mathrm{Zn}$ cations (Sałaciński and Gąsiński 2012). These results provided grounds to check the applicability of these beidellite-rich clays for constructing waterproofing barriers (e.g., Majer 2003; Łukwiński and Szczęśniak 1995; Wysokiński ed. 2007; Ratajczak ed. 2011, 2012; Panna et al. 2012). Currently they are utilized in such barriers, among others in the disposal site of flyashes in the Bełchatów Power Plant. 


\section{The aim of the investigations}

The project was focused on establishing the applicability of the beidellite clays of the Szczerców field of the Bełchatów lignite deposit to constructing waterproofing barriers.

The range and methodology of the investigations were adjusted to the aim specified above and included three research areas:

- the determination of the mineral nature, chemical composition and grain size distribution of the clays. The methods involved mineralogical of X-ray diffraction and chemical analyses, and grain size determination of the aerometric method;

- the determination of the physico-chemical properties of the clays. The methods involved the measurements of the specific surface area (nitrogen adsorption) and of the cation sorption capacity;

- the determination of such geological-engineering parameters as degree of compaction (relative density) using a Proctor device (to establish the optimum and maximum moisture contents and the bulk framework density), the values of the shrinkage, plastic and liquid limits, the values of the liquid and shrinkage indexes and the parameter A of Skempton's clay activity.

\section{Results}

The beidellite clays of Bełchatów have varying colors. They may be grey, bluish grey, green and yellow-green.

\subsection{Grain size distribution}

The beidellite clays are characterized by very similar distributions of their grain sizes (Fig. 2). A more detailed systematic position of the clays has been obtained following the criteria of R. Stevens (1983), based on the contents of the clay (below $2 \mu \mathrm{m})$, silt $(60-2 \mu \mathrm{m})$ and sand (above $60 \mu \mathrm{m}$ ) fractions. The results are contained in rather narrow ranges:

- clay fraction $-18.5-23.2 \%$ by weight,

- silt fraction $-73.6-79.7 \%$ by weight,

- sand fraction $-0.4-3.3 \%$ by weight.

Positions of the results within the triangle of Stevens (1983) classifies the clay rocks as claystones or weakly plastic claystones (Fig. 3) with a significant content of the sand fraction. 


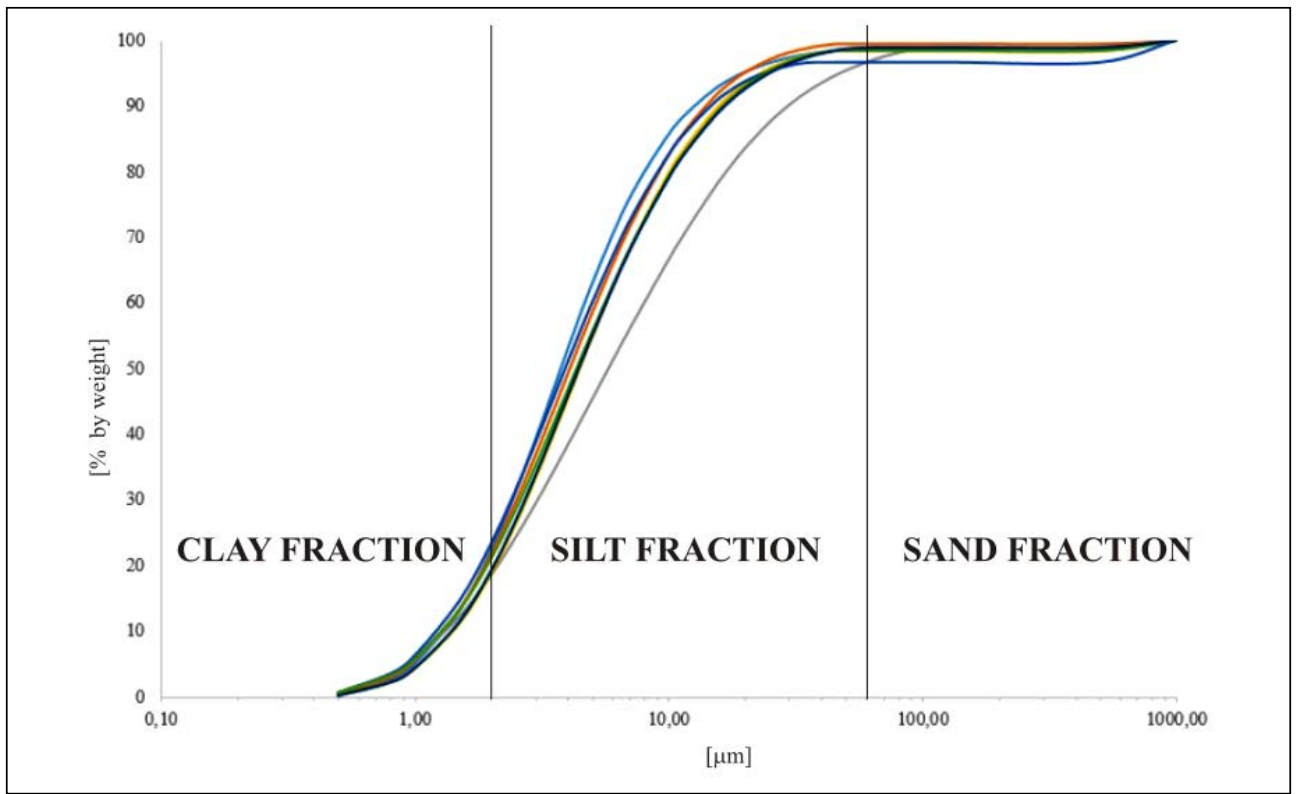

Fig. 2. Grain size distribution (cumulating curves) of the beidellite clays from the Bełchatów lignite deposit color marked for subsequent test samples

Fig. 2. Zakres uziarnienia (krzywa kumulacyjna) iłów beidelitowych ze złoża węgla brunatnego Bełchatów kolorem zaznaczono kolejne badane próbki

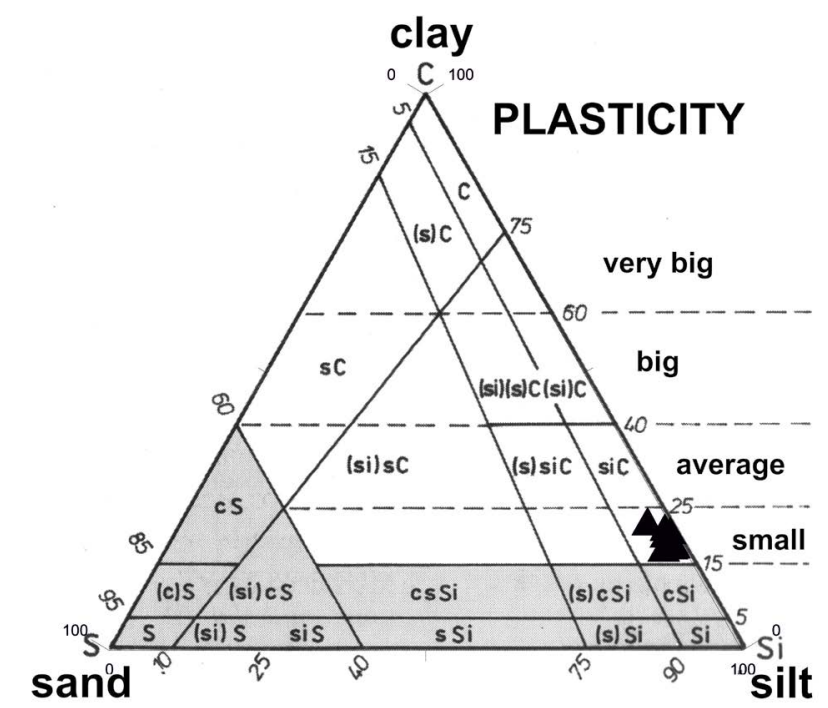

Fig. 3. The systematic position of investigated beidellite clays from the Bełchatów lignite deposit presented on the Stevens systematic triangle (1983)

Fig. 3. Pozycja systematyczna badanych iłów beidelitowych ze złoża węgla brunatnego Bełchatów przedstawiona na trójkącie klasyfikacyjnym Stevens’a (1983) 


\subsection{Chemical composition}

The chemical composition of the beidellite clays (Table 1) shows their relatively high, as in the case of clay rocks, contents of $\mathrm{Al}_{2} \mathrm{O}_{3}(22.28-30.57 \%$ by weight) and a rather distinct presence of $\mathrm{Fe}_{2} \mathrm{O}_{3}(2.18-4.20 \%$ by weight). In turn, as low can be considered the contents of:

- alkalis, since the totals of $\mathrm{K}_{2} \mathrm{O}$ and $\mathrm{Na}_{2} \mathrm{O}$ do not exceed $1 \%$ by weight,

- $\mathrm{CaO}$ that ranges between 0.90 and $1.75 \%$ by weight,

- organic substances between 0.32 and $0.89 \%$ by weight (the clays are poor in carbonaceous matter),

- sulfur, which recalculated to $\mathrm{SO}_{3}$ ranges between 0.17 and $0.50 \%$ by weight.

The amount of $\mathrm{CaCO}_{3}$ is insignificant and is contained in the range $1.60-4.69 \%$ by weight This range means that according to Wyrwicka and Wyrwicki's (1994) criteria, the beidellite clays of Bełchatów belong to non-calcareous (below $2 \% \mathrm{CaCO}_{3}$ by weight) and weakly calcareous $\left(2-10 \% \mathrm{CaCO}_{3}\right.$ by weight) clay varieties.

Table 1. Chemical composition of the beidellite clays from the Bełchatów lignite deposit (\% by weight)

Tabela 1. Skład chemiczny iłów beidellitowych ze złoża węgla brunatnego w Bełchatowie (\% wag.)

\begin{tabular}{|l|c|}
\hline \multicolumn{1}{|c|}{ Component } & Content \\
\hline $\mathrm{SiO}_{2}$ & $57.68-66.32(61.57)$ \\
\hline $\mathrm{TiO}_{2}$ & $0.31-0.61(0.47)$ \\
\hline $\mathrm{Al}_{2} \mathrm{O}_{3}$ & $22.28-30.57(26.48)$ \\
\hline $\mathrm{Fe}_{2} \mathrm{O}_{3}$ & $2.18-4.21(3.57)$ \\
\hline $\mathrm{CaO}$ & $0.90-2.63(1.42)$ \\
\hline $\mathrm{MgO}$ & $0.62-1.35(1.04)$ \\
\hline $\mathrm{MnO}$ & $0.01-0.13(0.02)$ \\
\hline $\mathrm{K}_{2} \mathrm{O}$ & $0.33-0.89(0.65)$ \\
\hline $\mathrm{Na}_{2} \mathrm{O}$ & $0.03-0.08(0.06)$ \\
\hline $\mathrm{SrO}$ & $0.01-0.01(0.01)$ \\
\hline $\mathrm{SO}_{3}$ & $0.05-0.17(0.10)$ \\
\hline $\mathrm{P}_{2} \mathrm{O}_{5}$ & $0.00-0.14(0.06)$ \\
\hline $\mathrm{Losses}_{3}$ on ignition & $2.90-5.20(3.86)$ \\
\hline $\mathrm{Organic}$ matter & $0.32-0.89(0.50)$ \\
\hline $\mathrm{CaCO}_{3}{ }^{*}$ & $1.60-4.69(2.54)$ \\
\hline
\end{tabular}

Note: figures in parentheses are the averaged values.

* $\mathrm{CaCO}_{3}$ content determined by complexometric titration. 
Considering the waterproofing properties of the clays in question, their low sodium contents (only $0.08 \%$ by weight on the average) may be a negative factor. The lack of sodium or its low contents are disadvantageous with respect to plasticity and swelling properties of clay rocks (Panna et al. 2012).

\subsection{Mineral nature}

The mineral composition of the beidellite clays was established using X-ray diffraction. The shapes of the X-ray patterns (Fig. 4) are almost identical, which is a sign of the almost same mineral composition of the samples. The samples were tested naturally, glycollated and roasted at $1000^{\circ} \mathrm{C}$. The interpretation of the $\mathrm{dhkl}$ values indicate that the clay rocks generally represent a monomineral, beidellite type. Kaolinite nature occur in traces. Neither reflections of illite nor the reflections of iron phases are present. Therefore, it can be deduced that the iron assayed in the amounts $2.28-4.14 \% \mathrm{Fe}_{2} \mathrm{O}_{3}$ by weight is associated with beidellite. The calcium type of this mineral is indicated by much higher amounts of $\mathrm{CaO}$ $\left(0.90-1.75 \%\right.$ by weight) than those of $\mathrm{Na}_{2} \mathrm{O}(0.03-0.08 \%$ by weight $)$.

The mineral nature of the clays present within the clay-sand complex of the Bełchatow deposit was studied by Wyrwicki (1993). He established beidellite as the major mineral component ( $43-62 \%$ by weight), kaolinite as the minor one (19-36\% by weight), while illite as the trace one. His XRD analyses determined that beidellite has a variable ordering of its internal structure, ranging between weakly and well ordered. From the shapes of derivatographic curves, particularly the inflection of the endothermal effect of the beidellite

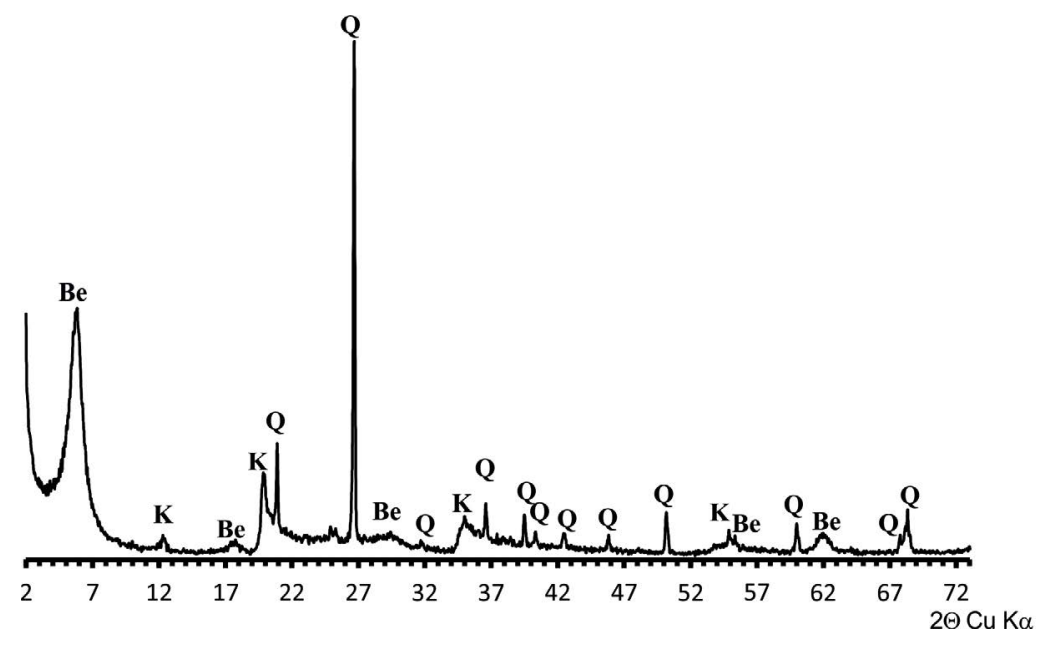

Fig. 4. The phase composition of beidellite clays from the Bełchatów lignite deposit $\mathrm{Be}$ - beidellite, $\mathrm{K}$ - kaolinite, $\mathrm{Q}$ - quartz

Fig. 4. Skład fazowy iłów beidellitowych ze złoża węgla brunatnego Bełchatów Be - beidellit, K - kaolinit, Q - kwarc 
at around $200^{\circ} \mathrm{C}$ which indicates a two-stage reaction, he postulated that beidellite has bivalent cations in its structure. The results of his analyses indicate the cation to be $\mathrm{Ca}^{2+}$.

Investigations of Górniak et al. (1999) and Bahranowski et al. (1999) indicated that the mineral composition of the clays from Bełchatów is dominated by smectite and kaolinite. Their detailed analyses established that the smectite is dioctahedral and has $\mathrm{Ca}^{2+}$ and $\mathrm{Mg}^{2+}$ in its interlayer spaces, whereas the kaolinite is structurally low-ordered. The detrital material, evenly distributed within the clay rock groundmass, is represented by angular grains of quartz, flakes of muscovite, grains of heavy minerals and iron microconcretions.

Panna et al. (2012) analyzed an amount of minerals of the smectite group in the beidellite clays of Bełchatów using the sorption of methylene blue method at around $56 \%$ by weight and also identified kaolinite as the accompanying clay mineral. The ion exchange capacity of the clay rocks of Bełchatów - around $580 \mathrm{mval} / \mathrm{kg}$, is another parameter given by these authors. Similar results were obtained by Gąsiński and Sałaciński (2012), who established the content of beidellite at above $60 \%$ by weight, while that of kaolinite at $10-15 \%$ by weight. The current authors studied a set of diversified samples, which represented the varieties of the beidellite clays that also differ in the content of the sand fraction. Such a clay rock variability is a reason of the differences in the chemical composition of the smectite, which generally ranges within the limits of the beidellite-montmorillonite solid solution. There are distinct differences in the composition of the interlayer cations: in part of the samples $\mathrm{Ca}^{2+}$ prevails over $\mathrm{K}^{+}$, while in the other part the amount $\mathrm{Ca}^{2+}$ is lower but that of $\mathrm{K}^{+}$higher than in the first group. The highest sorption capacity has been found just in the rock varieties with the highest amounts of $\mathrm{Ca}^{2+}$ at lower amounts of ${ }^{\mathrm{K}+}$.

\subsection{Beidellite clays of Belchatów as adsorbents}

The beidellite clays of Bełchatów were recognized as mineral adsorbents on the basis of their specific surface area and cation exchange capacity determinations (CEC).

The specific surface area SBET was measured with the method of low-temperature nitrogen sorption/desorpion using an ASAP MP HD device. It was established based on the linear form of the Brunauer-Emmet-Teller (BET) equation, measuring the physical nitrogen adsorption at $77 \mathrm{~K}$.

The ion exchange capacity of the beidellite clays was measured for $\mathrm{Ca}, \mathrm{Mg}, \mathrm{Na}, \mathrm{K}, \mathrm{Fe}$ and $\mathrm{Al}$ cations, applying the methods of atomic absorption spectroscopy (AAS) and flame photometry.

The beidellite clays of Bełchatów have their values of specific surface area in the range from 58.23 to $63.94 \mathrm{~m}^{2} / \mathrm{g}$. The values of their cation exchange capacity change between 316.8 and $574.1 \mathrm{mval} / \mathrm{kg}$. The $\mathrm{Ca}^{2+}$ cation revealed the highest adsorption $(90 \%$ of its amounts) and the sequence of cation adsorption was $\mathrm{Ca}^{2+}>\mathrm{Mg}^{2+}>\mathrm{K}^{+}>\mathrm{Na}^{+}$.

The values of the physico-chemical parameters that define the sorption properties of the beidellite clays of Bełchatów are similar to those of other domestic clay rocks of comparable 
mineral compositions. For instance, the Miocene Krakowiec clays from the Carpathian Foredeep and the Miocene-Pliocene Poznań clays (Table 2) - belong to this group. The figures obtained by the current authors do not differ much from those established in previous years. However, they differ distinctly from those of the Carboniferous montmorillonite clays of Milowice that are considered one of the best domestic mineral clay adsorbents.

Table 2. Values of the specific surface area and the cation exchange capacity of selected clay rocks of Poland

Tabela 2. Zestawienie wartości powierzchni właściwej oraz pojemności jonowymiennych różnych odmian skał ilastych Polski

\begin{tabular}{|c|c|c|c|c|c|}
\hline \multirow{2}{*}{\multicolumn{2}{c|}{ Parameter }} & \multicolumn{4}{|c|}{ Clay rock variety } \\
\cline { 2 - 6 } & $\begin{array}{c}\text { beidellite clays } \\
\text { of Bełchatów } \\
\text { (this study) }\end{array}$ & $\begin{array}{c}\text { beidellite } \\
\text { clays of } \\
\text { Bełchatów } 1\end{array}$ & $\begin{array}{c}\text { Krakowiec } \\
\text { clays }^{2}\end{array}$ & $\begin{array}{c}\text { Poznań } \\
\text { clays }^{3}\end{array}$ & $\begin{array}{c}\text { Milowice } \\
\text { bentonites }^{4}\end{array}$ \\
\hline Specific surface area $\left(\mathrm{m}^{2} / \mathrm{g}\right)$ & $58.23-63.94$ & $51-68$ & around 40 & $32-58$ & 114 \\
\hline Ion exchange capaccity $(\mathrm{mval} / \mathrm{kg})$ & $316-574$ & $350-480$ & around 300 & around 360 & $380-740$ \\
\hline
\end{tabular}

1 Ratajczak et al. 1992.

2 Stoch et al. 1977.

3 Kłapyta and Żabiński 2008.

4 Kłapyta 2008.

\subsection{Physico-mechanical properties of the clays of Bełchatów}

The physico-mechanical properties of the beidellite clays of Bełchatów were determined with the aim of establishing their applicability to constructing waterproofing barriers. Their list includes: degree of compaction (relative density) using a Proctor device (to establish the optimum $\left(\mathrm{W}_{\mathrm{opt}}\right)$ and maximum ( $\left.\mathrm{W}_{\max }\right)$ moisture contents and bulk framework density), the values of the shrinkage $\left(\mathrm{W}_{\mathrm{s}}\right)$, plastic $\left(\mathrm{W}_{\mathrm{p}}\right)$ and liquid $\left(\mathrm{W}_{1}\right)$ limits, the values of the liquid $\left(\mathrm{L}_{1}\right)$ and shrinkage (SI) indexes, hydraulic conductivity, and Skempton's clay activity (A parameter). These determinations were conducted according to the Polish standard PN-88/B-04481, and their results are listed in Table 3.

Some of these parameters (plastic index, hydraulic conductivity and Skempton's clay activity A) are considered by Wysokiński (2007) the standard determinations for establishing the suitability of clay rocks in constructing waterproofing barriers.

The beidellite clays belong to the rocks of the low plastic index. Its values falling in the range $61.07-87.46 \%$ means that none of them represents the rock of the highest waterproofing suitability. On the other hand, their hydraulic conductivity values in the range from $2.3 \times 10^{-11} \mathrm{~m} / \mathrm{s}$ to $9.4 \times 10^{-10}$ fully meet the criteria required (Wysokiński 2007) for the 
Table 3. The physico-mechanical parameters of the beidellite clays of the Bełchatów lignite deposit

Tabela 3. Parametry fizykomechaniczne iłów beidellitowych ze złoża węgla brunatnego w Bełchatowie

\begin{tabular}{|c|c|}
\hline Parameter & Range (average value) \\
\hline Natural moisture content (Wn) & $12.93-34.85(24.30 \%)$ \\
\hline Optimum moisture content (Wopt.) & $23.70-27.80(25.98 \%)$ \\
\hline Shrinkage limit (Ws) & $12.28-20.92(16.75 \%)$ \\
\hline Plastic limit (Wp) & $25.73-37.52(32.27 \%)$ \\
\hline Liquid limit (WL) & $92.49-121.60(103.49 \%)$ \\
\hline Liquid index (L1) & $-0.3-0.01(-0.11)$ \\
\hline Plastic index (Ip) & $61.07-87.46(71.21 \%)$ \\
\hline Shrinkage index (SI) & $8.83-21.86(15.52 \%)$ \\
\hline Hydraulic conductivity & $2.3 \times 10^{-11}-9.4 \times 10^{-10}\left(2.1 \times 10^{-10} \mathrm{~m} / \mathrm{s}\right)$ \\
\hline Skempton's clay activity (A parameter) & $2.62-4.65(3.42)$ \\
\hline
\end{tabular}

waterproofing materials. Such values are typical of rocks with a very low hydraulic conductivity. The values determined are characteristic of the clay rocks with beidellite as the major clay mineral.

Another important parameter to be considered in case of waterproofing is Skempton's activity coefficient A, which was established according to the Polish standard PN-86/B-02480. It is calculated as a ratio of plastic index to the clay fraction contribution of a rock and describes the rock ability to bind water. There are three classes of the A parameter:

- non active clays (A is less than 0.75),

- normal clays (A ranges between 0.75 and 1.25),

- active clays (A is more than 1.25).

In the tested beidellite clays, the A parameter changes from 2.62 to 4.65 and indicates that these rocks are highly suitable for constructing waterproofing barriers.

\section{Conclusions}

1. The clay rocks of the clay-sand complex of the of the Bełchatów lignite deposit represent the beidellite varieties. Their mineral composition, grain size distribution and sorption properties decide upon their identification to be mineral adsorbents.

2. Another property, i.e. their suitability to construct waterproofing barriers, has been assessed on the basis of grain size, chemical, mineral and physico-mechanical investigations, whose results were compared to the requirements contained in „Aprobata techniczna..." (2002). The following conclusions have been drawn: 
- the rocks contain $45-62 \%$ by weight of the grains finer than $0.5 \mu \mathrm{m}$. It means that their grain size distribution classifies them as belonging to the best or good classes of the suitability;

- the chemical composition, particularly the $\mathrm{SiO}_{2}$ content above $55 \%$ by weight and that of $\mathrm{Al}_{2} \mathrm{O}_{3}$ in the range of $22-30 \%$ by weight, classifies suitability of the rocks as good in the case of silica and the best or good in the case of alumina;

- the plasticity index equal between 61 and $76 \%$ does not meet the suitability criteria;

- the domination of beidellite among clay minerals is a cause that the clays are moderately suitable or unsuitable. It means that their using for waterproofing purposes will require a modification of the mineral composition;

- the values of cation exchange capability are high and change in a wide range of $320-570 \mathrm{mval} / \mathrm{kg}$. In this respect, the clays are well or moderately suitable. The sequence of the cation adsorption is $\mathrm{Ca}^{2+}>\mathrm{Mg}^{2+}>\mathrm{K}^{+}>\mathrm{Na}^{+}$.

3. Considering the criteria of Wysokiński (2007), the clays belong to the varieties with not an overly high plasticity index and, as such, cannot be regarded as a mineral raw material with the highest waterproofing suitability. However, another assessment criterion of these rocks is advantageous: their hydraulic conductivity is very low and ranges from $2.3 \cdot 10^{-11}$ to $9.4 \cdot 10^{-10} \mathrm{~m} / \mathrm{s}$. These figures are characteristic of the clay rocks rich in the minerals of the smectite group and due to this the filtration parameter classifies them as suitable for waterproofing constructions.

4. Summarizing, the beidellite clays of the clay-sand complex of the Bełchatów lignite deposit possess good or moderate values of the sorption parameters. They are capable of stopping the migration of the cations hazardous for the soil-water environment. They represent the mineral material suitable for constructing waterproofing barriers in the case of landfills. Such an evaluation has been accepted despite the fact that the beidellite clays of Bełchatów do not fully meet some suitability criteria of the geological engineering nature.

5. On a wider scale, these investigations exemplify the issue of identifying associated mineral raw materials of an economic potential, which is particularly important in the case of the open-cast exploitation of lignite deposits, among others those in the Bełchatów region. The results of the study have revealed a possibility of utilization of such rocks, unique from the geological point of view but of an economical significance.

The study falls within the range of the statutory research of two institutions: the Chair of Mineralogy, Petrography and Geochemistry, AGH-UST in Krakow (No. 11.11.140.319) and the Mineral and Energy Economy Research Institute of the Polish Academy of Sciences in Krakow, and was prepared in the year 2016. 


\section{REFERENCES}

Aprobata techniczna IMUZ/18-0011-00 do stosowania w budownictwie melioracyjnym roztworu hydroizolującego na bazie glin polimineralnych. Instytut Melioracji Użytków Zielonych w Falentach. 2002.

Bahranowski et al. 1999 - Bahranowski, K., Gaweł, A., Górniak, K., Muszyśki, M., Ratajczak, T., Szydłak, T. and Wyszomirski, P. 1999. Skład mineralny skał ilastych z kopalni węgla brunatnego Bełchatów w aspekcie ich surowcowego wykorzystania. Górnictwo Odkrywkowe R. XLI, z. 1, pp. 93-106.

Bajda, T. and Ratajczak, T. 2005. Możliwości wykorzystania bełchatowskich iłów beidellitowych jako sorbentów pierwiastków toksycznych na przykładzie związków chromu. Górnictwo Odkrywkowe vol. 47, No. 2, pp. 39-43.

Brański P. 1994. Możliwości wykorzystania iłów serii poznańskiej w ochronie środowiska. Przegląd Geologiczny Vol. 42, No. 6, pp. 446-449

Czarnecki et al. 1992 - Czarnecki, L., Frankowski, R. and Ślusarczyk, G. 1992. Syntetyczny profil litostratygraficzny utworów trzeciorzędowych złoża Bełchatów dla potrzeb Bazy Danych Geologicznych. Górnictwo Odkrywkowe Vol. 34, No 3-4, pp. 103-111.

Gąsiński, A. and Sałaciński, R. 2012. Kopaliny ilaste z nadkładu KWB „Bełchatów” pole Szczerców - skład mineralny a parametry surowcowe. Górnictwo Odkrywkowe Vol. 53, No 1-2, pp. 90-96.

Górniak et al. 1999 - Górniak, K., Szydłak, T., Bahranowski, K., Gaweł, A., Muszyński, M. and Ratajczak, T. 1999. Skład mineralny kopalin towarzyszących węglom oraz odpadów poflotacyjnych w aspekcie ich wykorzystania jako składników mieszanek popiołowo-mineralnych. Prace Specjalne PTMiN Vol. 13, pp. 35-43.

Jończyk, W.M. and Skórzak, M. 2001. Złoże węgla brunatnego Bełchatów - porównanie występowania kopalin towarzyszących w polu „Bełchatów” i w polu „Szczerców”. Górnictwo Odkrywkowe Vol. 43, No. 2-3, pp. 38-50.

Kłapyta, Z. 2008. Skały montmorillonitowe Górnośląskiego Zagłębia Węglowego [W:] Sorbenty mineralne. Monografia pod red. Z. Kłapyty and W. Żabińskiego. Kraków: Wyd. Naukowo-Dydaktyczne AGH, pp. 20-30.

Kłapyta, Z. and Żabiński, W. 2008. Ity poznańskie [W:] Sorbenty mineralne. Monografia pod red. Kłapyty Z. and Żabińskiego W. Kraków: Wyd. Naukowo-Dydaktyczne AGH, pp. 46-53.

Łukwiński, L. and Szczęściak, H. 1995. Iły jako surowce do masowego uszczelniania gruntów. Materiały Ogniotrwate No. 3, pp. 93-96.

Majer, E. 2003. Zastosowanie iłów beidellitowych z nadkładu KWB „Bełchatów” S.A. jako materiału do budowy składowisk odpadów. Górnictwo Odkrywkowe Roczn. 45, No. 6, pp. 56-61.

Panna et al. 2012 - Panna, W., Wyszomirski, P. and Motyka, J. 2012. Możliwości wykorzystania wybranych surowców smektytowych jako materiałów do celów hydroizolacyjnych. Zeszyty Naukowe Instytutu Gospodarki Surowcami Mineralnymi i Energia PAN No. 83, pp. 131-145.

PN-88/B-04481. Grunty budowlane. Badania próbek gruntów.

PN-86/B-02480. Grunty budowlane. Określenia, symbole, podział i opis gruntów.

Ratajczak et al. 1992 - Ratajczak, T., Bahranowski, K. and Olkiewicz, S. 1992. Wstępna ocena właściwości powierzchniowych, jonowymiennych i kwasowych iłów z Bełchatowa. Zeszyty Naukowe AGH, Geologia Vol. 18 No. 4, pp. 117-128.

Ratajczak, T. red. 2011. Wykazanie możliwości wykorzystania iłów i szlamów w charakterze składnika ultradrobnych spoiw hydroizolacyjnych. Archiwum Przedsiębiorstwa Robót Geologiczno-Wiertniczych Janik G., Kuś R., s.j.

Ratajczak, T. red. 2012. Ustalenie składu granulometrycznego, mineralnego i chemicznego skat ilastych (itu beidellitowego) z KWB „Betchatów”. Archiwum Przedsiębiorstwa Robót Geologiczno-Wiertniczych Janik G., Kuś R., s.j.

Ratajczak et al. 2015 - Ratajczak, T., Hycnar, E. and Bożęcki, P. 2015. Kryterium mineralogiczne jako element oceny przydatności niektórych polskich surowców ilastych do budowy przesłon hydroizolacyjnych. Studia, Rozprawy, Monografie nr 194, Kraków: Wyd. IGSMiE PAN, pp. 144.

Ratajczak et al. 2007 - Ratajczak, T., Hycnar, E., Jończyk, M.W. and Skórzak, A. 2007. Kompleksowe wykorzystanie kopalin towarzyszących a problemy rewitalizacji terenów pogórniczych na przykładzie złoża węgla brunatnego „Bełchatów”. Górnictwo i Geoinżynieria Roczn. 31, No. 2, pp. 519-532.

Ratajczak et al. 2005 - Ratajczak, T., Jończyk, W. and Skórzak, A. 2005. Ekologia a kopaliny towarzyszące na przykładzie złoża węgla brunatnego „Bełchatów”. Górnictwo Odkrywkowe Roczn. 47, No. 2, pp. 34-38. 
Ratajczak, T. and Stachura, E. 2004. Wytypowanie polskich skat ilastych w powiazaniu z ich regionalnym wystepowaniem w kontekście wykorzystania do potrzeb modyfikacji gruntów i wykonania przesłon hydroizolujących. Archiwum Katedry Mineralogii, Petrografii i Geochemii AGH.

Rozporządzenie Ministra Środowiska z dnia 24 marca 2003 roku w sprawie szczegółowych wymagań dotyczących lokalizacji, budowy, eksploatacji i zamknięcia, jakim powinny odpowiadać poszczególne typy składowisk. Dziennik Ustaw 2003, No 61, poz. 549.

Sałaciński, R. and Gąsiński, A. 2012. Możliwości wykorzystania gospodarczego surowców ilastych z plioceńskich iłów z KWB „Bełchatów” pole Szczerców. Górnictwo Odkrywkowe Roczn. 53, No 1-2, pp. 83-89.

Stevens, R. 1983. A new sand- silt-clay triangle for textural nomenclature. Geologica Föreninges. Stockholm Föhaudlinger Vol. 105, Issue 3, pp. 245-2650

Stoch et al. 1977 - Stoch, L., Bahranowski, K., Gątarz, Z. and Środoń, J. 1977. Charakterystyka mineralogiczna iłów nadkładowych złoża siarki w Machowie koło Tarnobrzega. Kwartalnik Geologiczny Vol. 21, No. 2, pp. 291-309.

Wyrwicka, K. and Wyrwicki, R. 1994. Waloryzacja złóż kopalin ilastych (z mapa 1 : 750 000). Warszawa: Wyd. PIG, 80 pp.

Wyrwicki, R. 1993. Potrzeba ochrony beidellitowych iłów z KWB Bełchatów. Przegląd Geologiczny Vol. 41, No. 9, pp. 612-620.

Wysokiński, L. red. 2007. Zasady oceny przydatności gruntów spoistych Polski do budowy mineralnych przesłon izolacyjnych. Warszawa: Wyd. Instytutu Techniki Budowlanej, 62 pp.

\title{
ILY BEIDELLITOWE ZE ZLOŻA WĘGLA BRUNATNEGO BELCHATÓW
} JAKO SUROWIEC DO BUDOWY PRZESLON HYDROIZOLACYJNYCH

\author{
Słowa kluczowe \\ składowiska odpadów, przesłony hydroizolacyjne, kationy metali ciężkich, \\ sorbenty mineralne, iły beidellitowe z Bełchatowa
}

\section{Streszczenie}

Składowiska odpadów, zarówno przemysłowych jak i komunalnych, z uwagi na charakter zgromadzonych materiałów jak i zachodzące w nich przemiany fizyczne, chemiczne i biologiczne stanowią zagrożenie dla środowiska naturalnego, a przede wszystkim gleb oraz wód gruntowych i powierzchniowych. Produkty tych przemian ulegają rozprzestrzenieniu na znaczne odległości, powodując degradację środowiska naturalnego. Jedną z metod ograniczających te zjawiska są naturalne przesłony hydroizolacyjne. Zbudowane ze skał ilastych mogą pełnić funkcję naturalnych barier geologicznych.

W pracy przedstawiono wyniki badań składu mineralnego i chemicznego, uziarnienia a także właściwości fizykochemicznych i fizykomechanicznych iłów beidellitowych ze złoża węgla brunatnego w Bełchatowie. Dokonano tego w celu wykazania ich przydatności do budowy przesłon hydroizolacyjnych. Dla określania tej przydatności stosowano kryteria stanowiące treść „Aprobaty technicznej..." (2002) oraz zaproponowane przez Wysokińskiego (2007). Uzyskane wyniki badań wskazują, że bełchatowskie iły beidellitowe spełniają stawiane wymagania i wykazują przydatność do budowy mineralnych barier hydroizolacyjnych w składowiskach odpadów. 
THE BEIDELLITE CLAYS FROM THE BELCHATÓW LIGNITE DEPOSIT AS A RAW MATERIAL FOR CONSTRUCTING WATERPROOFING BARRIERS

\author{
Keywords \\ landfill sites, waterproofing barriers, cations of heavy metals, mineral adsorbents, \\ beidellite clays, Bełchatów
}

Abstract

Disposal sites for both industrial and communal waste are hazardous for the natural environment due to the accumulated materials and their chemical, physical and biological transformations. The products of these processes migrating at a significant distance contaminate mainly underground waters, surface waters and soils. The spreading of the pollutants may be prevented by horizons of clay rocks that form natural geological barriers. The clay rocks of properly selected parameters may be used in the environmental engineering for constructing artificial water-sealing layers.

The mineral, chemical, physico-chemical and physico-mechanical properties of the beidellite clays occurring within the lignite deposit in Bełchatów were studied to find out whether they meet the criteria of waterproofing engineering contained in the Polish recommendations and instructions. The results indicate that the beidellite clays of Bełchatów are rocks suitable for this kind of environmental engineering and may be used in constructing the barriers preventing the migration of effluents from landfills. 
